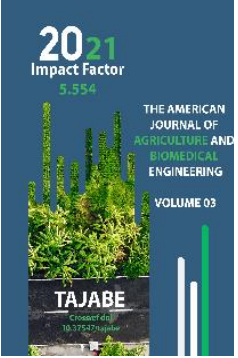

\section{Potato Moth-In Uzbekistan}

\author{
Dilshod Obidzhanov \\ Doctor Of Philosophy Of Agricultural Sciences (PhD), Scientific Research Institute Of HV And \\ V Named After Academician M.Mirzaev, Uzbekistan
}

Shokir Zokirov

Doctoral Student, Uzbek Research Institute Of Plant Protection, Uzbekistan
Journal Website: https://theamericanjou rnals.com/index.php/ta jabe

Copyright: Original content from this work may be used under the terms of the creative commons attributes 4.0 licence.

\title{
ABSTRACT
}

More than 10 types of the basic pests have been revealed in the territory of various soil-climatic zones of the Republic. Among them are adventive kinds -the Colorado potato beetle, the whitefly and the potato moth. Biological features of those types and seasonal dynamics of their development are established; the general tactic of protective methods are developed with application of progressive means and receptions. Precautionary receptions of potato tubers' protection against potato moth are established and recommended.

\section{KEYWORDS}

Potato Moth, Rust Mite, Whitefly, Biology, Insecticides, Ways Of Protection, Efficiency.

\section{INTRODUCTION}

More than ten different varieties of common pests have been discovered in the Republic's distinct soil-climatic zones. The Colorado potato beetle, whitefly, and potato moth are examples of adventive type. The main tactic of protective methods is developed with the application of progressive means and receptions; biological properties of types and seasonal dynamics of their development are established. The protection of potato tubers against potato moth is established and suggested through precautionary receptions. 
On a boundary of 2009 in the territory of northern areas of the Republic the centers of potato moth (P.operculella) spreading rather quickly have been found out and nowadays it is registered on a half of the territory of the Republic (including the capital area). It was required to study urgently morphologicbiological features of development of a kind in new ecological conditions of habitation and to begin developments under the prevention of development and protection of plants and tubers from this new pest. The study began in 2010 by employees of UzSRIPP in the territory of the Khorezm region and is proceeding nowadays in the Tashkent region $[1,2,3]$.

It is established that the basic part of the wintered butterflies of the moth appearfrom favorable winter storage conditions (cellars, storehouses, premises, etc.). Being a representative of kinds from the tropical countries an all-the-year-round continuous food is peculiar to it. In conditions of the Central Asia with snowless low winter temperatures of air the kind should not survive in the conditions of an open air. The publications also tell about it. According to V.N.Zhimerikin and V.M.Dudov (2009) the potato moth ceases to develop at air temperature $10^{\circ} \mathrm{C}$ and at $3-5^{\circ} \mathrm{C}$ it dies out. But there is no unambiguous answer. Some scientists consider that the kind can sometimes endure considerable colds up to $-8^{\circ} \mathrm{C}$ like in the South Korea (K.R. Choe, L.S. Park, 1982) - on V.A.Vlasova (1986) [5, 6].

\section{PLACE AND TECHNIQUE OF RESEARCHES}

Monitoring of susceptibility to infection of a potato by pests was spent all over the territory of the Republic, and experiments and routing supervision were held on fields of Khorezm, Tashkent and Fergana regions. In research work the various methods recommended for these purposes (Gar, 1974; Dospekhov, 1979; Recommendations of Biological Monitoring Department of SRI, 1986; Khodzhaev, 2004) have been used.

\section{RESULTS OF EXPERIMENTS AND THEIR DISCUSSION}

Our researches have shown that butterflies' flight on fields continues to the late fall while the potato tops do not perish from the cold. Caterpillars inside the tubers also endure low temperatures and continue feeding on the potato until it is frozen. Thus, the pest has practically a possibility to winter in the field conditions in a stage of caterpillars being inside the earthed tubers (left after cleaning). Caterpillars inside the tubers do not perish at a storage time in cellars and storehouses, but duration of their development is stretched, nevertheless from November till next April they can give 2-3 generations (in warmer premises - up to 5 generations). So, the main task both in tubers' infections prevention and their preservations for storage, is maintenance of cleanliness of tubers left on storage. There are different conditions for this purpose in the Republic though it depends partly on precocity of grades. In northern conditions of the Khorezm region the colds come earlier, than at the other regions. It causes earlier destruction of potato tops. And consequently, prior to the beginning of harvesting the caterpillar have time having gone down from plants to penetrate into tubers. In other areas with potato cultivation, the crop is usually harvested at green tops. It can be convenient, from the point of view that the tops of 
vegetable are mowed down and cleaned from a field before harvesting that does not allow tubers to be infected primary with caterpillars.

And, the second condition of prevention of tubers' infestation with butterflies' eggs rafting (especially at manual cleaning) is crop's fast cleaning from a field.

Studying of development phenology of a kind during a season has shown that butterflies' flight and their density occurs from small to bigger. In April it is possible to reveal the first butterflies of the moth, but they are very insignificant. Gradually by the autumn the butterflies' density increases and, to the beginning of September on 10 double waves of a net (see Fig.) come across to 7-8 butterflies of the moth. Fig. 2 presents the results of seasonal studying of potato moth butterflies' flight on potato fields in two geographically remote regions of the Republic.

From figure it follows that the basic part of potato moth dominates in SeptemberNovember both in one, and in other region.

Owing to recent penetration of potato moth to the territory of Uzbekistan, the pest has not many natural enemies yet. The entomophages need time to have been adapted to it.

For establishment of possibility of insecticides control against potato moth during growth of plants and establishment of the list of effective preparations, we provided a tactic of these processings and preparations testing. Tactics is that in view of practical impossibility of caterpillars' destruction inside the stalks, the scientifically-proved term of processings was the moment of mass flight and butterflies' eggs rafting. At absence of pheromone traps, these terms can be defined by insectary supervision over insects, and also butterflies' catch with nets in field conditions. It is required 3-4 processings for period of potato vegetation in this case. For achievement of the planned purpose is more comprehensible a tractor ventilatory sprayer OBX-28, but in small farm economy conditions the hinged manual sprayer with a motor (see Fig.) and having the expense of a working liquid to $250 \mathrm{l} / \mathrm{ha}$ is quite enough. One of such experiments has been spent for a season of 2021. A potato field of late term sowing has been divided into 8 plots (on $0,1 \mathrm{ha}$ ). On seven plots the various insecticides like imago and larvicides have been tested. There were 3 processings spent: on 29.VII, 10.IX and 24.IX. Accounts of butterflies' density were spent after each processing and of a biological efficiency - after the last processing within 11 days (Tab. 1). From the received results it follows that both the method and the tested insecticides have proved their value. No one potato tuber occupied by moth caterpillars has been found in comparison with control - 3,7$4,8 \%$. During wintering the potato moth development among experimental tubers was not revealed, among control was 2,3-4,2 \%.

Sometimes on potato tops it is possible to notice caterpillars of cotton worms (Helicoverpaarmigera Hb.) and caradrin (Spodopteraexqua Hb.) which occurrence is a general concern. Quite often on potato tops appears filicauline dodder (cuscuta) which control is to be spent locally. 
The American Journal of Agriculture and Boimedical Engineering (ISSN - 2689-1018)

Table 1

Biological efficiency of 3 multiple processings of potato crops against potato moth and other accompanying pests

Field experiment, the Tashkent region, the late term of crops - 25-27.VII.,

Processings are spent: 29.VIII, 10.IX and 24.IX.2021

\begin{tabular}{|c|c|c|c|c|c|c|c|c|c|c|c|}
\hline \multirow{3}{*}{$\begin{array}{c}\text { Experiment } \\
\text { variants }\end{array}$} & \multirow{3}{*}{$\begin{array}{c}\text { Active } \\
\text { substances of } \\
\text { preparations }\end{array}$} & \multirow{3}{*}{$\begin{array}{l}\text { Norms of } \\
\text { expense } \\
\text { on a } \\
\text { hectare, I } \\
\mathrm{kg} / \mathrm{ha}\end{array}$} & \multicolumn{9}{|c|}{ Efficiency, \% on days of accounts: } \\
\hline & & & \multicolumn{5}{|c|}{ Against butterflies on a site: } & \multicolumn{4}{|c|}{$\begin{array}{l}\text { On decrease of plants } \\
\text { injuriousness after } \\
\text { the } 3 \text { rd processing: }\end{array}$} \\
\hline & & & 1 & 5 & 9 & 16 & 23 & 1 & 3 & 7 & 11 \\
\hline $\begin{array}{l}\text { Enjoxam, } \\
24,7 \% \text { к.c. }\end{array}$ & $\begin{array}{c}\text { Lambdacigalotri } \\
\mathrm{n}+ \\
\text { Tiametoxam }\end{array}$ & 0,2 & 100 & $\begin{array}{c}88, \\
9\end{array}$ & $\begin{array}{c}89, \\
4\end{array}$ & 100 & $\begin{array}{c}99, \\
0\end{array}$ & $\begin{array}{c}90 \\
4\end{array}$ & $\begin{array}{c}97 \\
8\end{array}$ & $\begin{array}{c}95 \\
6\end{array}$ & $\begin{array}{c}94 \\
5\end{array}$ \\
\hline $\begin{array}{l}\text { Emaben, } \\
\text { cd.g.w. }\end{array}$ & $\begin{array}{c}\text { Emamectin } \\
\text { bensoat }\end{array}$ & 0,2 & 100 & $\begin{array}{c}87 \\
2\end{array}$ & $\begin{array}{c}87 \\
7\end{array}$ & 100 & $\begin{array}{c}93, \\
0\end{array}$ & 92,1 & $\begin{array}{c}96 \\
5\end{array}$ & 94 & $\begin{array}{c}92 \\
9\end{array}$ \\
\hline $\begin{array}{c}\text { Decis, } \\
\text { 2,5\%c.e.. }\end{array}$ & Deltametrin & 0,5 & 100 & $\begin{array}{c}89, \\
9\end{array}$ & $\begin{array}{c}90 \\
3\end{array}$ & 100 & $\begin{array}{c}95, \\
2\end{array}$ & $\begin{array}{c}90 \\
3\end{array}$ & $\begin{array}{c}95 \\
5\end{array}$ & $\begin{array}{c}94 \\
1\end{array}$ & 93 \\
\hline $\begin{array}{c}\text { Cypremetrin, } \\
25 \% \text { c.e.. }\end{array}$ & Cypremetrin & 0,3 & 100 & $\begin{array}{c}96, \\
6\end{array}$ & $\begin{array}{c}93 \\
5\end{array}$ & 100 & $\begin{array}{c}98, \\
0\end{array}$ & $\begin{array}{c}90 \\
1\end{array}$ & $\begin{array}{c}96, \\
5\end{array}$ & 94 & $\begin{array}{c}94, \\
3\end{array}$ \\
\hline $\begin{array}{l}\text { Imidogold, } \\
35 \text { \% к.с. }\end{array}$ & Imidocloprid & 0,2 & 100 & $\begin{array}{c}88, \\
9\end{array}$ & $\begin{array}{c}89, \\
4\end{array}$ & 100 & $\begin{array}{c}99, \\
0\end{array}$ & $\begin{array}{c}90 \\
4\end{array}$ & $\begin{array}{c}97 \\
8\end{array}$ & $\begin{array}{c}95, \\
6\end{array}$ & $\begin{array}{c}94 \\
5\end{array}$ \\
\hline $\begin{array}{l}\text { Control } \\
\text { (without } \\
\text { rocessing) }\end{array}$ & - & - & - & - & - & - & - & - & - & - & - \\
\hline
\end{tabular}

\section{CONCLUSION}

Despite the wide list of harmful organisms occupying a potato, it is developed nowadays and constantly updating the system of control against them to provide their phyto-sanitary condition's monitoring, and conducting a complex of warning and destroying measures of control against them to ensure data of losses till the economic-imperceptible sizes. 


\section{REFERENCES}

1. Obidzhanov D.A., Khodzhaev Sh.T. Potato moth is a new pest of nightshade in Uzbekistan. // J. plant protection and quarantine - Moscow, 2014. - No. 11. -WITH. 43-44.

2. Obidjanov D.A. Potato moth - a new solanaceae pest in Uzbekistan. //Wschodioeuropejskie Czasopismo Naukowe. (East European Scientific Journal) - Czechia, 2016. - №8. - P. 67-69.

3. Obidzhanov D., Erkinov Kh. Potato pests in uzbekistan. //The American Journal of Agriculture and Boimedical Engineering (ISSN - 2689-1018). July 30, 2021. P. 11-20.

4. Zhimerikin V. N, Dudov M.V. Potato moth in the field and a storehouse / Plants protection and quarantine, 2009, №4, p.32-34.

5. Khodzhaev S.T. Entomology, protection of agricultural crops and basis of agrotoxicology./Tashkent: “Navruz”, 2013, p.540 (Uzb.)

6. Shelton A.M. Development and development of transgenic insecticidal crops in pest management.//Plant Protection towards 21st Century. Proceed. Of $X Y$ International Plant Protection Congress. - Beijing, China, 2004, - p.13-15. 